\title{
Rubber tree clonal plantations: grafted vs self-rooted plant material
}

\section{Aurélien MASSON ${ }^{1}$ \\ Olivier MONTEUUIS ${ }^{2}$}

\section{${ }^{1}$ SoGB estate}

SOCFIN Group

01BP 365, San Pedro

Côte d'Ivoire

${ }^{2}$ Cirad

Département Systèmes biologiques - Bios

UMR AGAP, TA A-108/03

Av. Agropolis

34398 Montpellier Cedex 5

France

Auteur correspondant / Corresponding author:

Aurélien Masson - amasson@sogbci.com

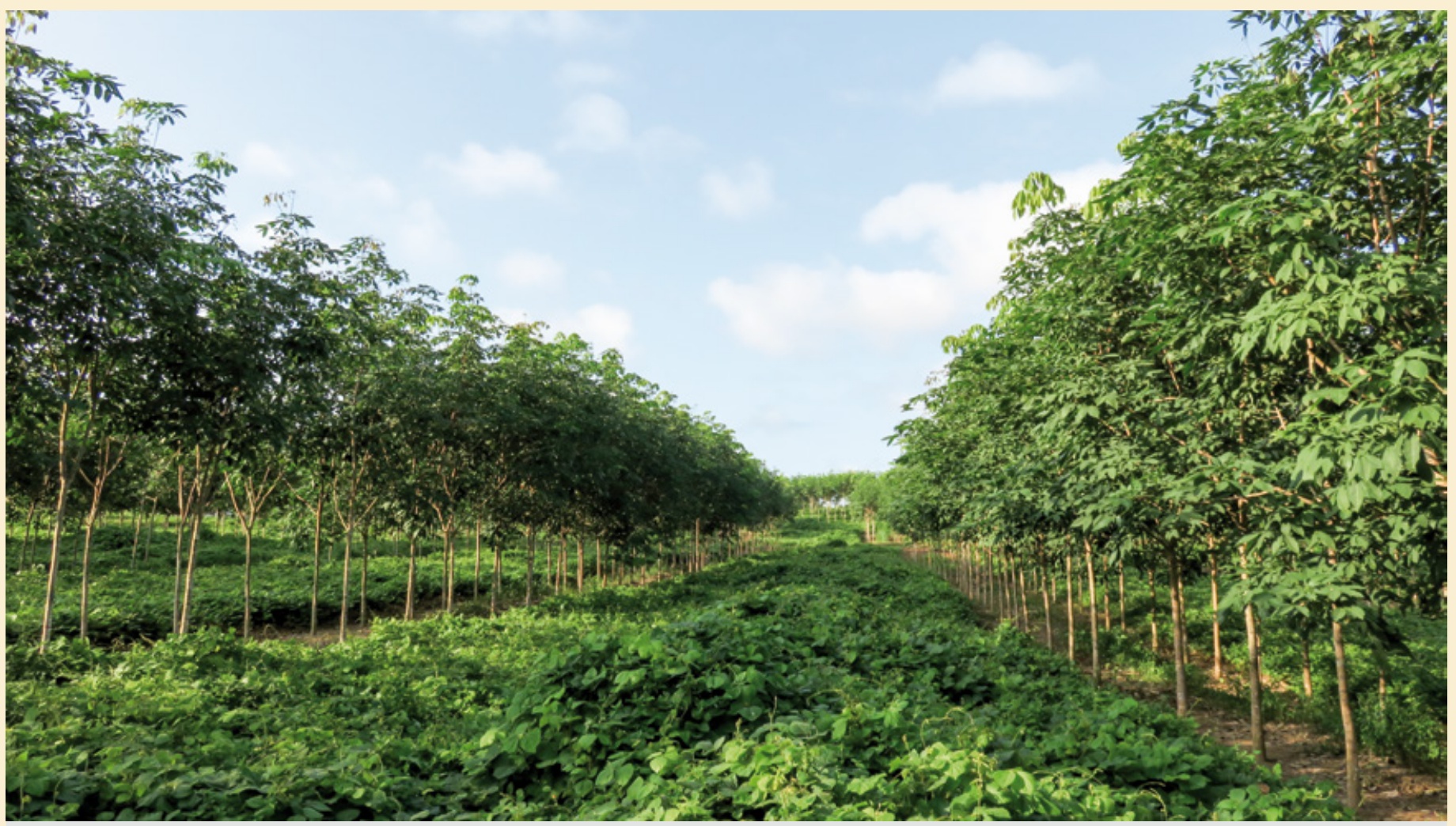

\section{Photo 1.}

H. brasiliensis industrial clone PB 235 produced from grafts (left) and from rooted cuttings (right) three years after planting at SoGB. Photo A. Masson. 


\section{RÉSUMÉ}

\section{PLANTATIONS CLONALES D'HÉVÉAS ISSUES DE GREFFES OU DE BOUTURES}

Hevea brasiliensis est une espèce arborescente intensément plantée sous les tropiques humides afin de satisfaire les besoins croissants en caoutchouc naturel. D'énormes quantités de plants sont nécessaires à cette fin. Si les semis constituent la solution la plus immédiate et la plus économique pour produire des hévéas, ceux-ci se révèlent très hétérogènes quant à la vigueur et à la productivité en latex. L'intérêt des clones pour remédier à cette hétérogénéité était déjà perçu dans les années 1910, mais les difficultés d'enraciner des pousses d'hévéas ont favorisé le greffage comme technique de clonage alternative. La remarquable augmentation de productivité et la plus grande uniformité constatées pour ces plantations de clones greffés ont favorisé leur essor au point de supplanter les semis dans la plupart des plantations industrielles. Néanmoins, le greffage présente aussi des inconvénients et durant des décennies, les efforts visant à produire à grande échelle des clones sélectionnés d'hévéas sur leurs propres racines par bouturage se sont poursuivis, avant d'être progressivement abandonnés faute de résultats probants. Durant les années 1970, la priorité a été donnée à la culture in vitro alors en plein essor. Mais, en dépit de 40 années d'investissement considérable, force est de constater que les clones industriels d'hévéas ne peuvent toujours pas être produits sur leurs propres racines à grande échelle. Cette situation est malgré tout susceptible de changer radicalement avec la mise au point de nouvelles techniques de pépinière permettant de bouturer en quantité n'importe quel clone d'hévéa sélectionné. Les efforts se poursuivent dans cette voie afin d'établir avec toute la rigueur requise si les clones sur leurs propres racines issus de bouturage produisent plus de latex que les génotypes greffés. Cette vieille question suscite un intérêt croissant du fait d'une pression foncière de plus en plus forte, limitant les possibilités d'extension des plantations d'hévéas.

Mots-clés : propagation clonale, boutures, culture in vitro, graines, greffes, Hevea brasiliensis, plants, racines.

\section{ABSTRACT}

\section{RUBBER TREE CLONAL PLANTATIONS: GRAFTED VS SELF-ROOTED PLANT MATERIAL}

The forest tree species Hevea brasiliensis is extensively planted in the humid tropics to meet the increasing demand for natural rubber. Huge quantities of planting stock are therefore needed. The seed option remains the easiest and cheapest way to establish plantations of rubber trees but those show a great variability for vigor and also for latex yield. The rationale of producing clones for overcoming this variability was already obvious in the early 1910's but due to the difficulties encountered at that time for rooting shoots, grafting was used as an alternative cloning method. The striking increase in yield noticed from the graft-derived clonal plantations warranted their large scale development. Eventually, the budded clones by virtue of their much higher and uniform productivity supplanted the seedlings in most industrial plantations. However, grafting is also associated with drawbacks and for decades efforts aiming at mass producing selected rubber tree clones on their own roots by rooted cuttings have been pursued. However, this approach was progressively abandoned due to disappointing rooting results and, from the 70's onwards, priority has been given to in vitro methods which were booming during this period. But despite 40 years of heavy investments, industrial $H$. brasiliensis clones could still not be mass micropropagated in vitro efficiently enough to meet the requirements of large scale production. The situation may change radically soon, however, due to the development of new nursery techniques adapted to the mass clonal production by rooted cuttings of any $\mathrm{H}$. brasiliensis selected genotype. Efforts to improve the techniques as well as the establishment of new field trials are underway in order to determine if self-rooted rubber tree clones are more productive than grafted ones. This old issue is becoming of overriding importance considering the increasing pressure on land availability reducing thereby the prospects for expanding rubber tree plantations.

Keywords: clonal propagation, cuttings, grafts, Hevea brasiliensis, planting stock, roots, seeds, tissue culture.
A. Masson, O. Monteuuis

\section{RESUMEN}

\section{PLANTACIONES CLONALES DE CAUCHO: MATERIAL INJERTADO FRENTE A MATERIAL CON RAÍCES PROPIAS}

Hevea brasiliensis es una especie arborescente intensamente sembrada en zonas tropicales húmedas para satisfacer la creciente demanda de caucho natural. Dada la enorme cantidad de plantas necesaria, las semillas constituyen la solución más rápida y barata para producir árboles de caucho, pero éstos muestran una gran heterogeneidad en cuanto al vigor y a la producción de látex. El interés de los clones para paliar dicha heterogeneidad se hizo patente ya desde 1910, pero debido a las dificultades de enraizamiento de los brotes, se favoreció el injerto como método alternativo de clonación. El notable incremento de la productividad y la mayor homogeneidad observada en estas plantaciones de clones injertados propició su expansión, sustituyendo a las semillas en la mayoría de plantaciones industriales. Sin embargo, el injerto también tiene inconvenientes y durante varias décadas se siguió intentando producir a gran escala clones seleccionados de caucho sobre sus propias raíces mediante estaquillado; pero como los resultados no eran satisfactorios, este método fue poco a poco abandonándose. En los años 70 se priorizó el cultivo in vitro, en pleno auge en aquel entonces. Pero, a pesar de llevar 40 años realizando considerables inversiones, hay que admitir que los clones industriales de caucho siguen sin poder producirse a gran escala sobre sus propias raíces. Con todo, esta situación puede cambiar radicalmente con la puesta a punto de nuevas técnicas de vivero que permiten la producción en masa de estacas enraizadas de cualquier genotipo de caucho seleccionado. Se están realizando esfuerzos en este sentido para determinar con el rigor necesario si los clones con sus propias raíces provenientes de estaquillado producen más látex que los genotipos injertados. Esta vieja cuestión está más que nunca de actualidad debido a la creciente presión sobre la tierra que limita las posibilidades de extensión de las plantaciones de caucho.

Palabras clave: propagación clonal, estacas, cultivo in vitro, semillas, injertos, Hevea brasiliensis, plantón de vivero, raíces. 


\section{Introduction}

Rubber has been utilized as early as Precolumbian times by Aztec and Mayan civilizations (Compagnon, 1986; Baulkwill, 1989). It was derived from the latex produced by Hevea brasiliensis, a forest tree species native to the Amazon basin under a wet equatorial climate with no distinct dry season. $H$. brasiliensis, commonly called rubber tree, exhibits a rhythmic growth endogenously controlled and develops according to the Rauh architectural model to reach up to $50 \mathrm{~m}$ in height in the natural environment (Hallé and Martin, 1968; Combe and du Plessix, 1974; Hallé et al., 1978). This species was soon recognized as the most effective producer of rubber among the ten Hevea spp. that have been identified so far i.e. $H$. benthamiana, $H$. camargoana, $H$. camporum, $H$. guianensis, H. microphylla, H. nitida, H. pauciflora, $H$. rigidifolia, $H$. sprucean $a$ and $H$. brasiliensis. They are all diploid with $2 n=36$ and able to cross interspecifically (Webster and Paardekooper, 1989). The attractiveness of rubber reached an international dimension during the second part of the $X I X^{\text {th }}$ century (Baulkwill, 1989). In order to meet the increasing needs of natural rubber, $H$. brasiliensis industrial plantations have been established in various tropical countries. Suitable sites are characterized by annual rainfalls of 1,800 to $2,500 \mathrm{~mm}$ with an optional drier season which should not be too pronounced (Watson, 1989). High hygrometry facilitates latex exudation but harvesting can be hindered by too much rain (Compagnon, 1986). Soils, slightly acidic, must be well drained as the species is sensitive to waterlogging, root diseases and diebacks (Baulkwill, 1989). Until the end of the XIX'th century, rubber latex was collected from trees growing naturally in the Amazon basin forests. The first attempts to planting rubber trees took place in Latin America but often sustained damage due to the fungus Microcyclus ulei. This fungus, still confined to Latin America, remains one of the most important threats to rubber plantations (Compagnon, 1986). These have expanded rapidly in Asia, starting with the introduction to Ceylon (now Sri Lanka) in 1876 of seedlings from the collection made by Wickham in Brazil, then to Africa where the species was introduced for the first time in 1893 (Compagnon, 1986; Baulkwill, 1989). The "rubber boom" in South East Asia occurred around 1910, benefitting from outcomes of the first genetic selections initiated by Dutch researchers in Java and Sumatra in 1910-20 (Baulkwill, 1989; Simmonds, 1989).

\section{Use of rubber trees produced from seeds}

\section{Seed formation in Hevea brasiliensis}

$H$. brasiliensis is a monoecious allogamic species that produces limited quantities of seeds per tree, possibly due to low maternal fertility (Clément-Demange et al., 2007). There is no evidence of self-incompatibility but certain genotypes such as clone GT 1 do not develop male flowers on the majority of their flowering shoots and can be therefore considered as male sterile (Edgar, 1958). This could be due to microspore abortion in the anthers during pollen formation (Leconte and Nicolas, 1985). Selfing is possible and can reach $16-28 \%$ in open pollinated trees (Simmonds, 1989), and likely more in isolated trees or within monoclonal blocks logically suspected to produce highly inbred seeds. However, surprisingly, this does not seem to be the case as seedlings so derived are used as rootstocks for industrial grafting (Clément-Demange et al., 2007).

The fruits usually contain 3 large seeds, weighing between 3.5 and $6.0 \mathrm{~g}$ each. The distinctive color pattern and shape of the testa (photo 2) can be reliably used for identifying the maternal origin of the seeds produced by the most common industrial clones (Compagnon, 1986; Webster and Paardekooper, 1989). Germination, the capacity of which drops quite rapidly, is hypogeal and occurs usually within 3-25 days after sowing (Dijkman, 1951; Webster and Paardekooper, 1989). The seedlings develop a strong tap root and extensive lateral roots (photo 3 ), the whole root system forming about $15 \%$ of the total dry weight of a mature tree (Compagnon, 1986). Feeder roots are mostly in the top $30 \mathrm{~cm}$ of the soil (Webster and Paardekooper, 1989).

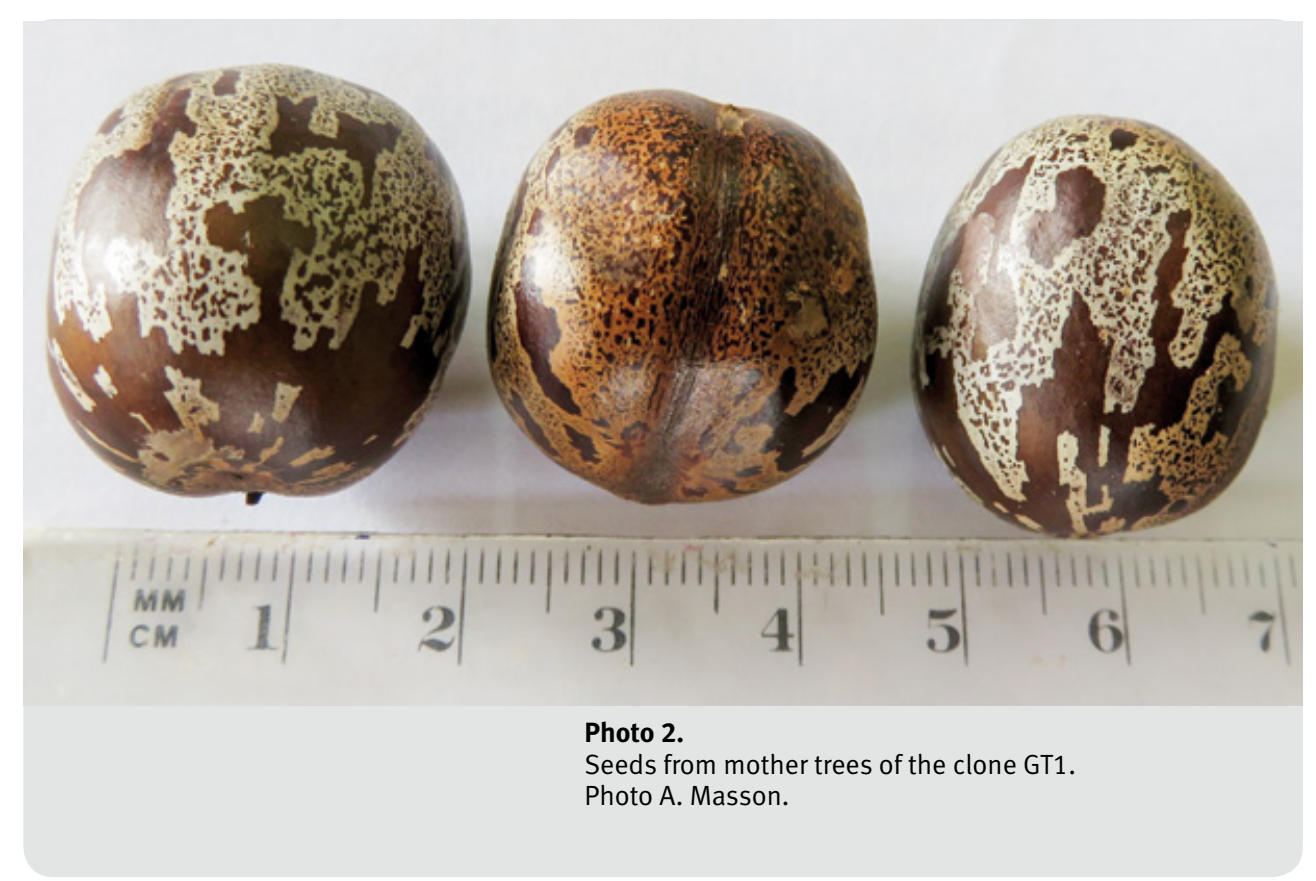




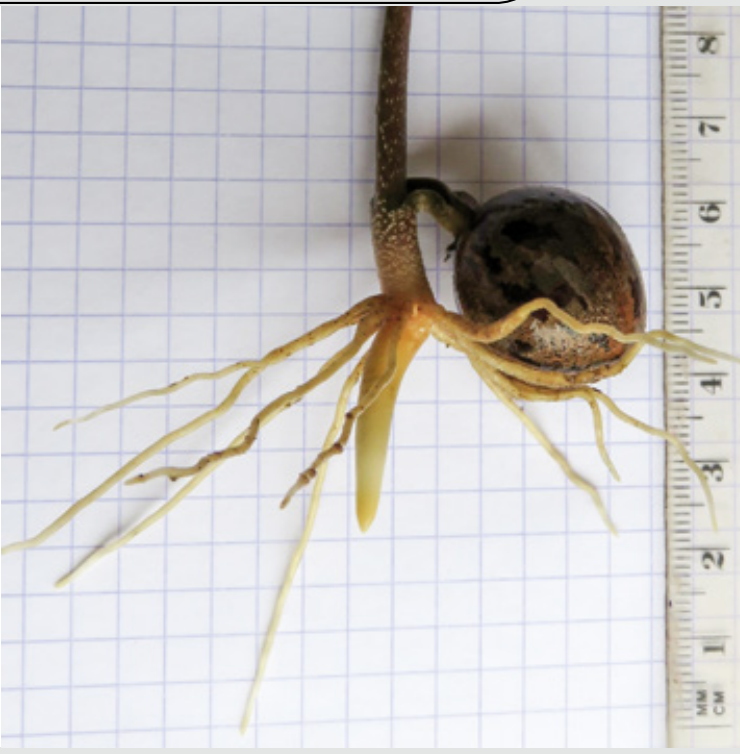

Photo 3.

Root system of a freshly germinated seedling. Photo A. Masson.

\section{For latex production}

Rubber tree planting stock devoted to latex production is expected to be easily accessible at an affordable price and to grow vigorously in a sufficiently large range of site conditions in order to produce soonest as much latex as possible.

Until the end of the XIXth century, rubber tree plantations were established exclusively from seeds, from the Wickham collection mainly, that was derived from trees growing naturally in the Amazon basin forests. As for many species, seeds remain the easiest and cheapest way of producing rubber tree planting stock.

However, rubber yield was early reported to vary greatly among seed-derived trees (Edgar, 1958; Simmonds, 1989). In 1919 , Whitby noticed that only $9.8 \%$ of a population of unselected seedlings produced $28 \%$ of the total latex harvested (Whitby, 1919). Such variations were hardly compatible with large scale plantation requirements. Then, until the 1940s, seeds collected from superior mother genotypes planted in monoclonal blocks were alternatively used as a source of more uniform planting material (Priyadarshan, 2011). The subsequent development of budded (grafted) clones prompted the big companies to restrict the use of seedlings to rootstock production, whereas seed-derived rubber trees for latex production, or "jungle rubbers", have since been mostly used by smallholders (Webster, 1989; Cardinal et al., 2007).

\section{For breeding activities}

As for many species, sexual reproduction with its attendant genetic recombinations plays a determining role in the genetic improvement of the rubber tree. Shortening the duration of the initial unproductive and as such economically unprofitable period before first tapping and latex yield, that are closely associated to vigor (Simmonds, 1989), are the major traits to improve (Clément-Demange et al., 2007). Breeding traits of secondary importance are wind-firmness, disease resistance, bark morphology and latex vessel plugging (Simmonds, 1989). The time needed for evaluating these traits and the low fertility of the mother trees remain major constraints on $\mathrm{H}$. brasiliensis genetic improvement.

\section{Use of grafted clones}

\author{
Grafting rubber trees
}

The main motive for producing rubber tree clones was to overcome the great variability, especially in latex yield, noticed among seed-derived trees (Dijkman, 1951; Simmonds, 1989; Webster, 1989) and thereby to increase crop productivity. Vegetative propagation of superior yielding trees by hardwood or softwood budding onto seedling rootstocks in active growth (photo 4) was and is still the most efficient and widely used grafting technique (Compagnon, 1986). It was initially developed and improved to be applied at an industrial scale by Van Helten, who established the first two clonal $H$. brasiliensis plantations in Java and Sumatra in February 1918 (Dijkman, 1951). The striking increase in yield noticed since 1927-28 from these clonal compared to seedling-derived plantations warranted the large scale development of rubber tree clonal plantations,

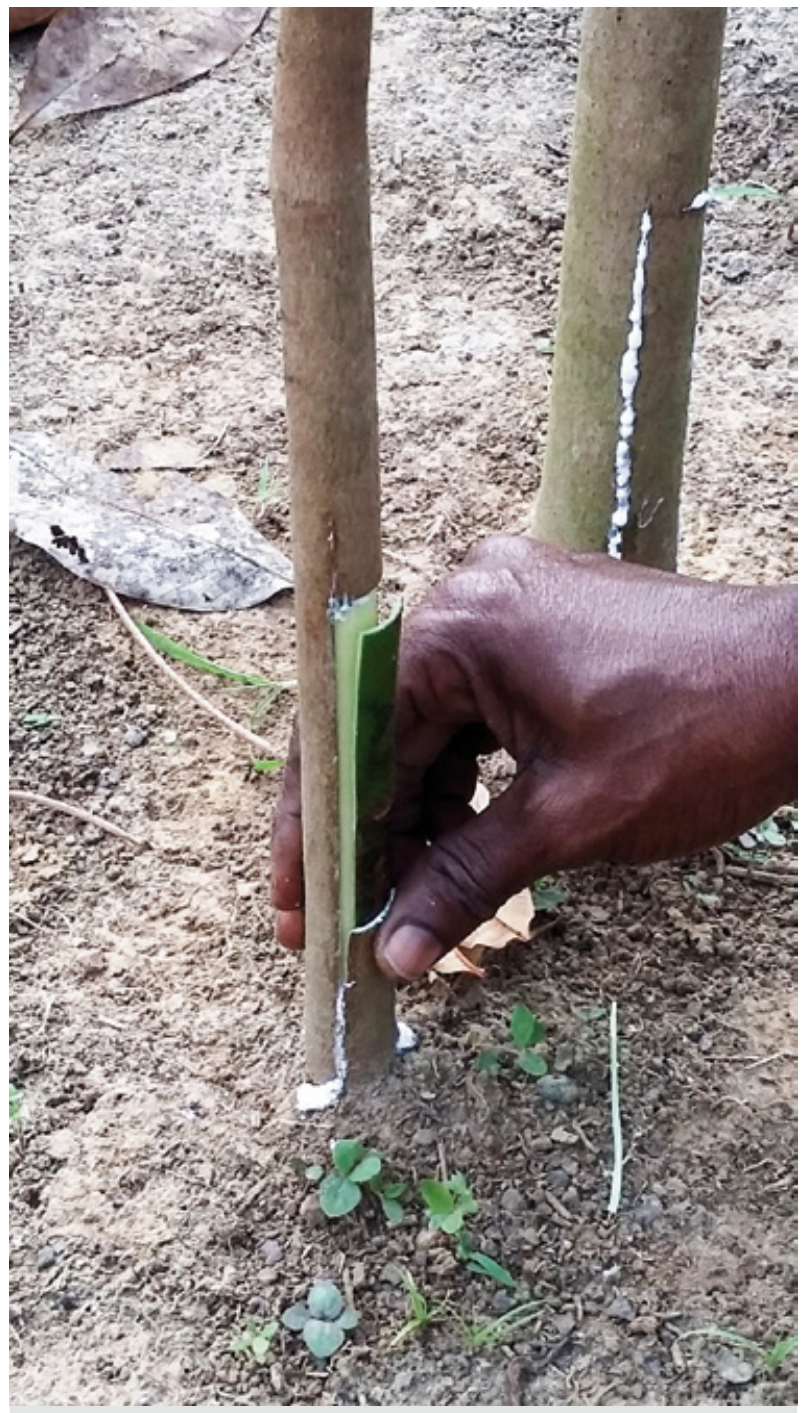

Photo 4.

Grafting rubber trees: positioning the bud patch in the window previously made on the rootstock. Photo A. Masson. 
whose superiority became internationally acknowledged around 1935 (Compagnon, 1986). Currently, all rubber tree clonal plantations consist of budded trees planted in monoclonal blocks, and that grow upon a genetically heterogeneous population of seedling rootstocks interacting with the clonal aerial parts (Simmonds, 1989; ClémentDemange et al., 2007).

A budded rubber tree, as any grafted plant, is a genetically composite individual comprising the genotype of the selected clone used as scion that is grafted onto the unselected seed-issued rootstock genotype. It combines i) the characteristics of the grafted genotype and of the one used as rootstock, ii) the interaction between these two symbionts and iii) the per se effect of grafting (Hartmann et al., 1997; Webster, 1989). The quality of the graft union can vary within the same clone grafted according to: $i$ ) the genotype and the physiological condition of the scions as well as of the different seedlings used as rootstocks, ii) the dexterity of the manipulator. This can account for the significant intraclonal variability reported for certain grafted clones of rubber trees (Clément-Demange et al., 2007). Wycherley (1969) considered that the main criterion for the choice of a rootstock was its influence on the vigor of the grafted clone. Like in fruit trees, it can be assumed that there is a positive interaction for this trait between the scion and the stock: the grafted clone would grow faster with a vigorous scion, and vice versa (Dijkman, 1951; Clément-Demange et al., 2007). Evidence of stock influence was observed during the first stages of grafting developments in the 1930s in Indonesia and in Malaysia, but so far without major incidence on the use of superior rootstocks for operational grafting (Baulkwill, 1989). Certain "clonal seed" origins collected from monoclonal blocks assumed to have been fertilized by the unknown pollen - so referred to illegitimates or "ill" - of neighboring "father" clonal blocks are giving better results than others for rootstock production (Compagnon, 1986; Webster, 1989). Possible advantages over unselected seeds are higher uniformity - they have at least half of their genetic background in common -, vigor and yield. This is the case for GT1 ill which, in addition of being male sterile and as such free of inbreeding-induced vigor depression, produces seeds profusely. Some other origins of clonal seeds can have a positive effect of compatibility for grafting, but induce poor vigor and latex yield, or good vigor and low latex production, as for instance PR 107 grafted on Tjir ill. In practice however, the choice of monoclonal seedling families as rootstocks is mainly dictated by the availability of seeds from clones fertile enough and abundantly planted.

"Double-working" by budding has also been applied to the rubber tree (Dijkman, 1951; Leong and Yoon, 1978; Compagnon, 1986; Webster, 1989). A double-worked plant consists of three parts: the rootstock, the grafted interstock and the grafted upper scion, which are all genetically different and are assembled by two grafting unions (Hartmann et al., 1997). In 1926, Cramer and De Vries suggested the production of double-worked rubber trees for commercial planting material combining (a) an ideal rootstock, (b) an ideal stem, and (c) an ideal crown (Dijkman, 1951). The aim was to counteract the negative effects that could arise from the unselected seedling-derived rootstock by budding onto a clone used as interstock or intermediate that would act as a "buffer". "Crown budding" was first tried in Java in 1926, then in Malaysia in the 1960s and 1970s where different clones were tested as interstocks with significant effects (Leong and Yoon, 1978). Double-working was found useful in some areas to confer wind and disease resistance on high-yielding clones lacking these qualities (Baulkwil, 1989). In Latin America, crown budding was used mainly as a measure against South American Leaf Blight (SALB), top grafting crowns from $H$. benthamiana, and especially $H$. pauciflora, clone PA31, that is more resistant/tolerant to SALB onto RRIM 600, one of the best high latex yielding interstock. But these heterografts exhibited a big species-induced difference in development between the crown and the trunk, exposing these three-part trees to higher risks of wind breakage and to a diminution of latex production. These drawbacks and the additional plant material resources, time and cost requirements associated with double working have been serious hindrances to the development of crown budding in the rubber tree, which has been restricted nowadays to a few places exposed to SALB, mainly in Mato Grosso, Brazil (Frank Rivano, personal communication).

\section{Pros}

Grafting has been and is still so far the only means of mass clonally propagating $H$. brasiliensis genotypes selected for their capacity to produce high yield of latex, to be planted as clones for a much higher and more uniform productivity of the plantations than when established from seedlings (Dijkman, 1951; Compagnon, 1986; Webster and Baulkwill, 1989). Grafting does not require sophisticated and well equipped facilities and can be implemented under basic conditions as long as suitable rootstocks, scions and workmanship are locally available. The grafted clones benefit from a good root system vigor and soil anchorage provided by the tap root of the seedlings used as rootstocks. They are also less exposed to clone-related risks of soil inadaptability and root disease owing to the higher genetic diversity of the seed-derived rootstock, each root system being genetically different one from another.

\section{Cons}

In contrast to these advantages, grafting can also be responsible in $H$. brasiliensis as for many other tree species for drawbacks (Webster, 1989). These result mainly from various forms of grafted clone $X$ rootstock genotype incompatibility (Hartmann et al., 1997; Webster, 1989; Cardinal et al., 2007). These incompatibilities can be localized and characterized by graft union deficiencies, but can be also more diffuse and time delayed in the case of translocated incompatibilities (Lachaud, 1975). Practically variation of graft union quality between the stock and the scion accounts for the intraclonal variability noticed within grafted clones, in addition to the genetic differences among the seedlings used as rootstocks (Clément-Demange et al., 2007). More 


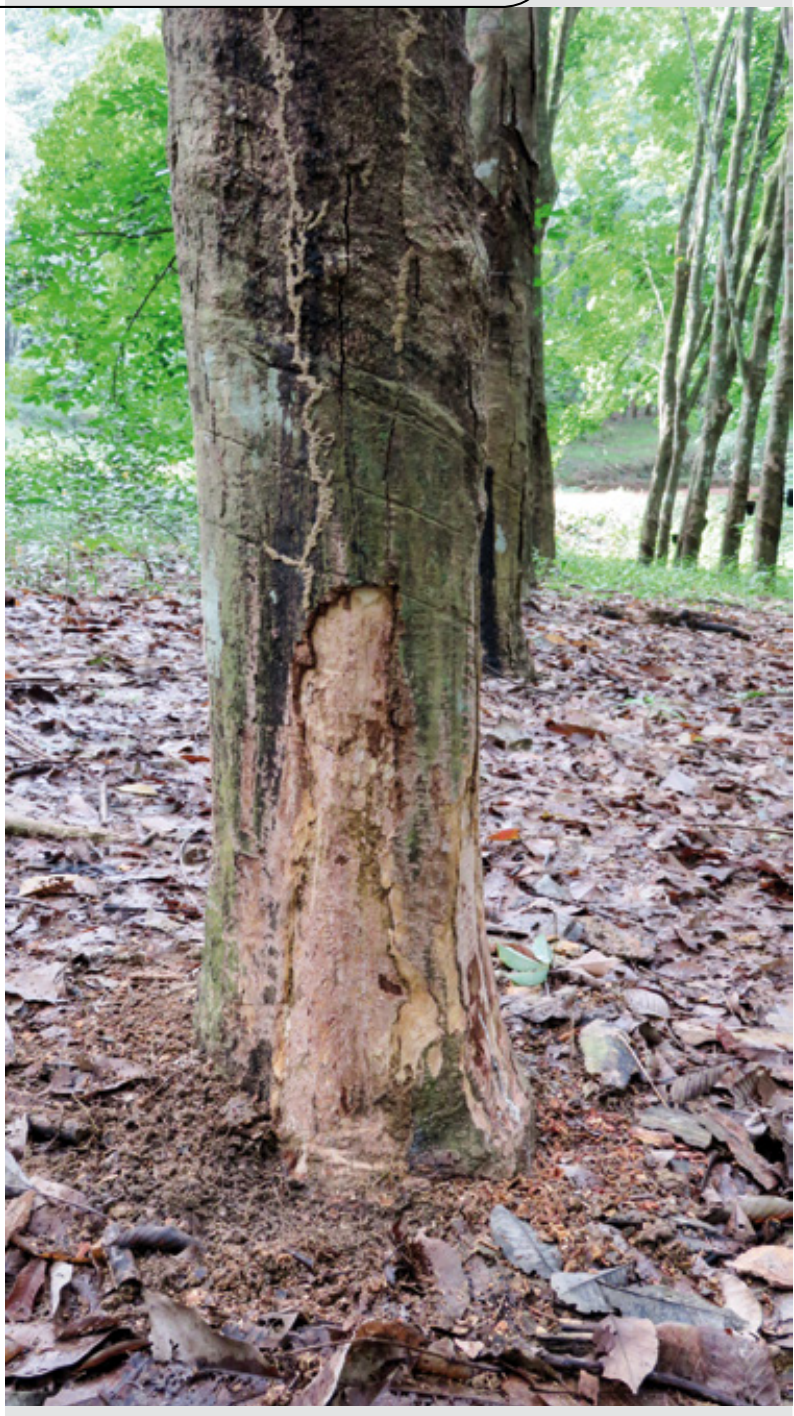

Photo 5.

Bark necrosis syndrome at the rootstock/scion union. Photo A. Masson.

specifically, the Bark Necrosis syndrome (photo 5), caused by a disequilibrium of cyanogenic potential and detoxification ability between the rootstock and the scion could result from such incompatibilities (Chrestin et al., 2004). All this may account for a decrease in latex yield for grafted or "twopart" plants compared to plants on their own roots (Dijkman, 1951; Compagnon, 1986; Cardinal et al., 2007).

The budding technique of grafting on the side of the stock promotes one sided and unbalanced development, at least in the early stages (photos 6) of the grafted plant, exposing it to higher risks of breakages, especially for certain clones more prone to wind damages than others.

Also, seedlings to be used as rootstocks and shoots for scion production must be produced in sufficient quantities and must have the suitable size and physiological condition to be successfully grafted by competent staff (Dijkman, 1951). All this requires proper planning, management and investment in terms of plant materials, areas and manpower.
Another issue is the advanced physiological age of the material produced by conventional budwood gardens: the buds used for budding are physiologically mature, accounting for the mature characteristics of the resulting graft-derived trees. These include a cylindrical trunk while the base below the union could exhibit an elephant foot shape (photos 7), a lower crown and the quantity of latex produced is less than for the mother tree (Dijkman, 1951; Priyadarshan, 2011).

Lastly, grafting does not provide the opportunity to field test the industrial clones on their own root systems: both the rootstock and the quality of graft union itself will always interfere.

\section{Use of self-rooted clones}

\section{Background}

The rationale of producing $H$. brasiliensis clones was already obvious in the early 1910's but the difficulties faced at that time for rooting of $\mathrm{H}$. brasiliensis shoots accounted for the development of grafting as an alternative to the mass production of self-rooted clones (Dijkman, 1951; Webster and Baulkwill, 1989). These have always been assumed to be more vigorous, bigger, less prone to the early production of lateral and axillary shoots, and to yield more latex than when produced by grafting (Dijkman, 1951; Pochet, 1965; Compagnon, 1986). So using self-rooted clones is expected to solve the grafting-induced drawbacks described previously. The possibility to test the industrial clones on their own roots has been a constant concern and remains a priority issue at the research and development levels (Dijkman, 1951; Compagnon, 1986; Webster, 1989).

\section{Production of self-rooted clones: practical options and achievements}

There are only two options of producing self-rooted clones of rubber trees: $i$ ) by adventitious rooting of cuttings or in vitro-produced microcuttings and ii) by in vitro somatic embryogenesis.

\section{Rooting of cuttings in local nursery conditions}

It was demonstrated in the beginning of the $X X^{\text {th }}$ century that rubber trees could be propagated by marcots and also by split seedlings but in too few numbers for large scale application (Dijkman, 1951; Edgar, 1958). Rooting cuttings was attempted earlier at the end of the XIXth century using softwood terminal shoots of $30 \mathrm{~cm}$ of average length but it was difficult to keep the shoots alive till the formation of adventitious roots occurred, especially for mature material (Warburg, 1902). This situation remained stagnant till Stahel (1947) improved significantly the rooting rates by using permanent fine water sprays. A few years later, Dijkman (1951) rooted shoots taken from the crown of 3 to 4 year-old resting seedlings that were placed in open air rooting beds under a similar water misting system. The adventitious roots formed when the new leaves developed looked like tap roots, which was considered as a promising indicator of suitability for field planting. Despite these encouraging results, propagation of 


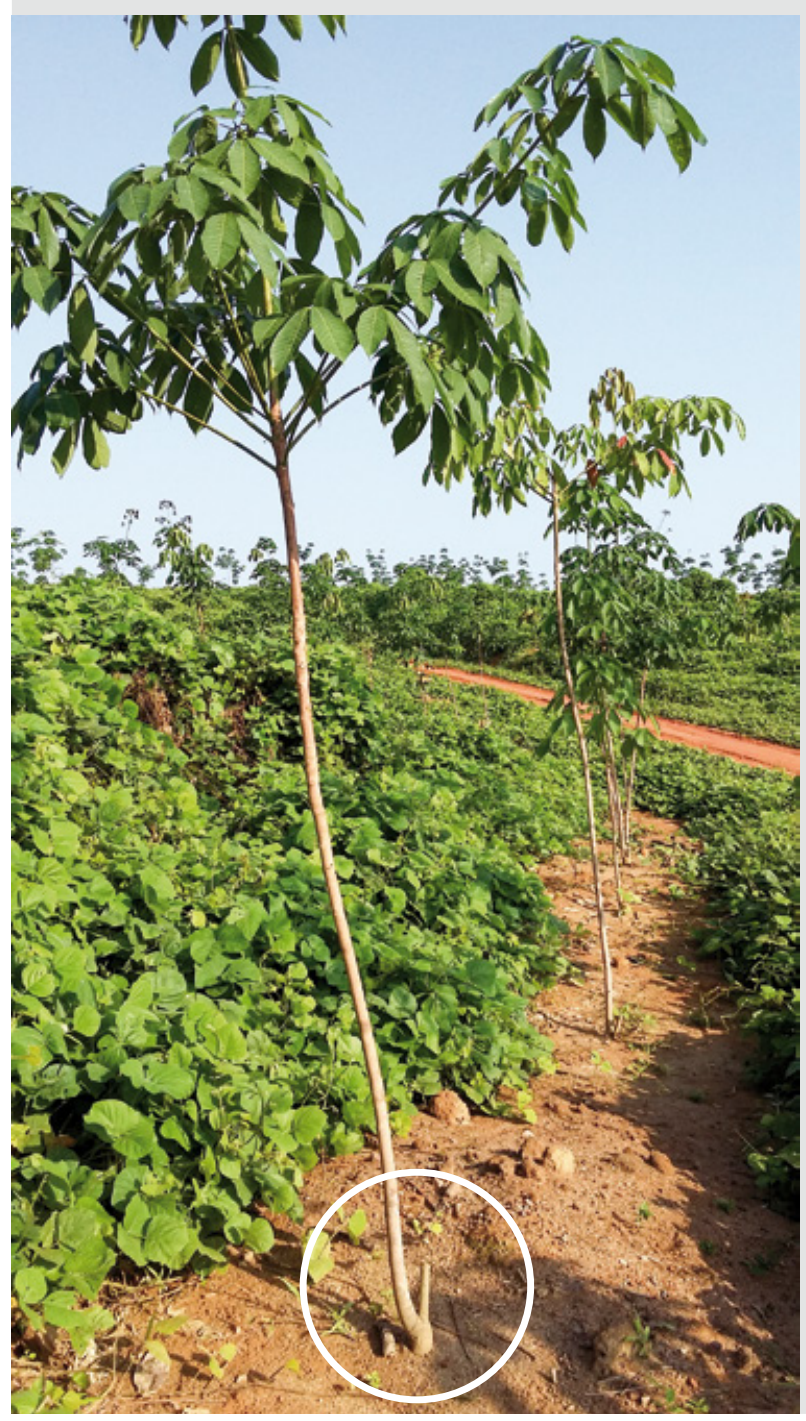

rubber tree by rooted cuttings was limited to juvenile materials until the mid-50's. Levandowsky in 1959 was the first one to succeed in getting rooted cuttings of mature materials maintained under an open air intermittent mist-system in nursery conditions (Lewandowsky, 1959). This technique was soon after used for rooting with up to $90 \%$ percent of success more than fifty rubber tree mature genotypes, with special mention of the clones PB86 and GT1 the most widely planted in Malaysia at that time (Tinley and Garner, 1960). Unfortunately the few initiatives that followed remained too scanty to induce a significant change and in the mid 1980's, Compagnon (1986) reported that none of the numerous attempts aiming at mass producing industrial rubber clones cost-effectively by rooted cuttings had really succeeded so far. This disappointing situation changed only in 2013 with, for the first time, the mass production by rooting cuttings of mature $H$. brasiliensis selected clones by the Socfin group at Société des caoutchoucs de Grand-Béréby, SoGB for short, in Côte d'Ivoire (Masson et al., 2013). This success was mainly due to proper plant material management as described in Monteuuis (1993) in suitable nursery facilities under natural conditions, always preferable for large scale application to artificial ones. Resorting to a reliable mist system

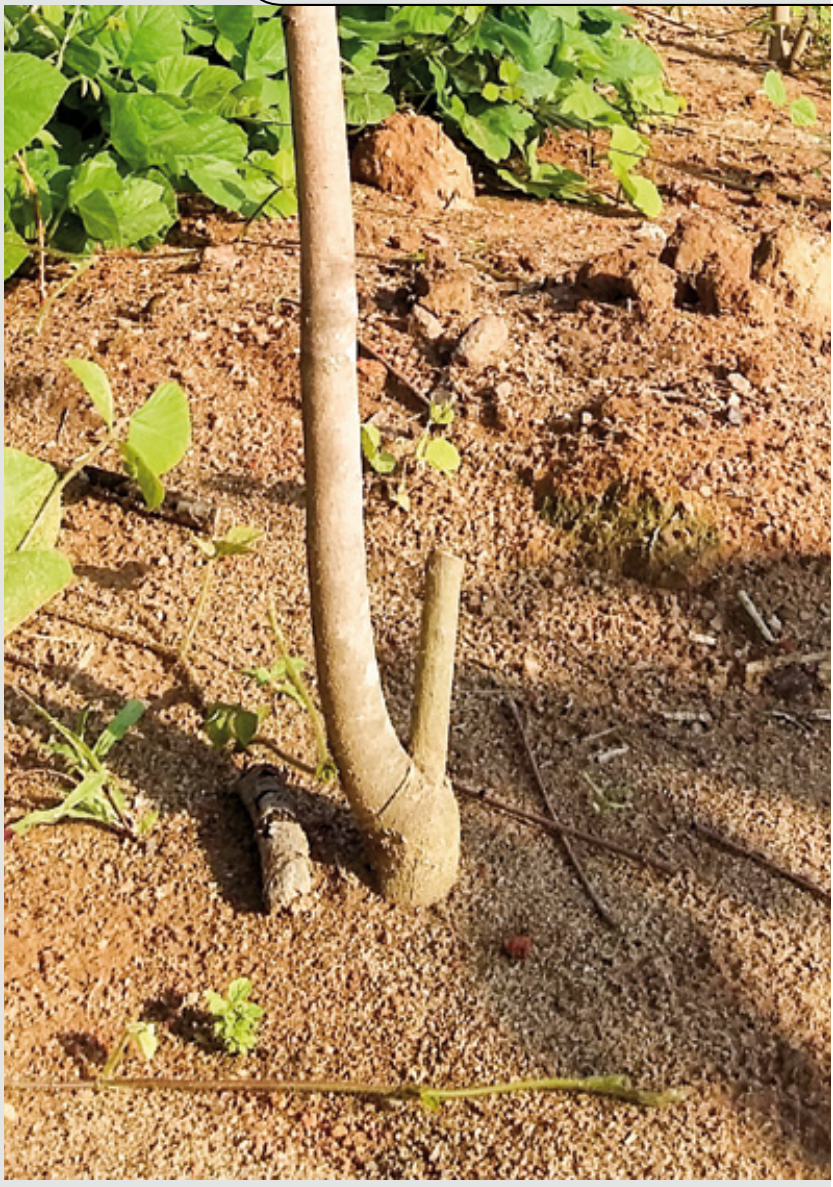

Photos 6.

One sided development of a newly budded rubber tree resulting from the side positioning of the grafted bud, with enlargement (right) of the grafting point (in circle).

Photos A. Masson.

had a determining beneficial effect on rooting, consistently with Stahel (1947)'s observation in more rudimentary conditions. Since then, the activities have been progressing to the extent that at present all the industrial clones tested by Socfin can be rooted in SoGB nursery facilities (Masson, unpublished results; photos 8 and 9). The rooted cuttings are either being used as stock plants to produce new cuttings, or are planted in sufficient numbers according to appropriate experimental layouts together with traditionally budded or tissue cultured plants of the same clones for comparative assessment of their field behavior.

\section{In vitro micropropagation and somatic embryogenesis}

From the 1970's, attempts to root rubber cuttings by traditional techniques were gradually abandoned to give the preference to in vitro micropropagation methods that were actively being developed at that time.

In vitro micropropagation by axillary budding of $H$. brasiliensis from field or container-grown plants has been initiated using shoot apices or shoot nodes as primary explants (Venkatachalam et al., 2007; Montoro et al., 2012). Shoot apical meristems or "SAM" are too tiny in $H$. brasiliensis to be used with sufficiently high success rates 

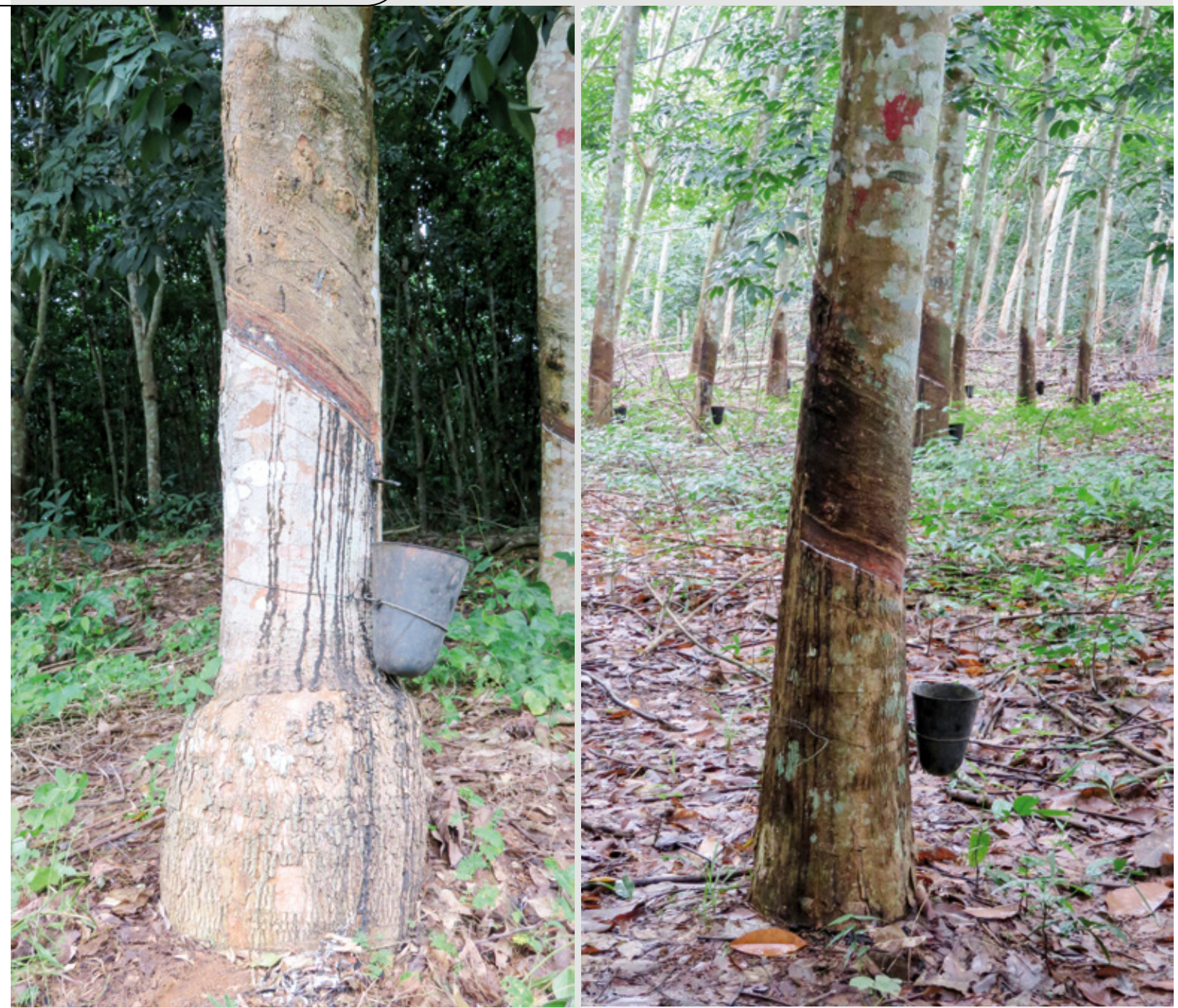

Photos 7.

Budded trees are prone to "elephant foot" deformities at the graft union (left) contrary to seed-derived trees characterized by a more conical, tapered trunk (right). Photo A. Masson.
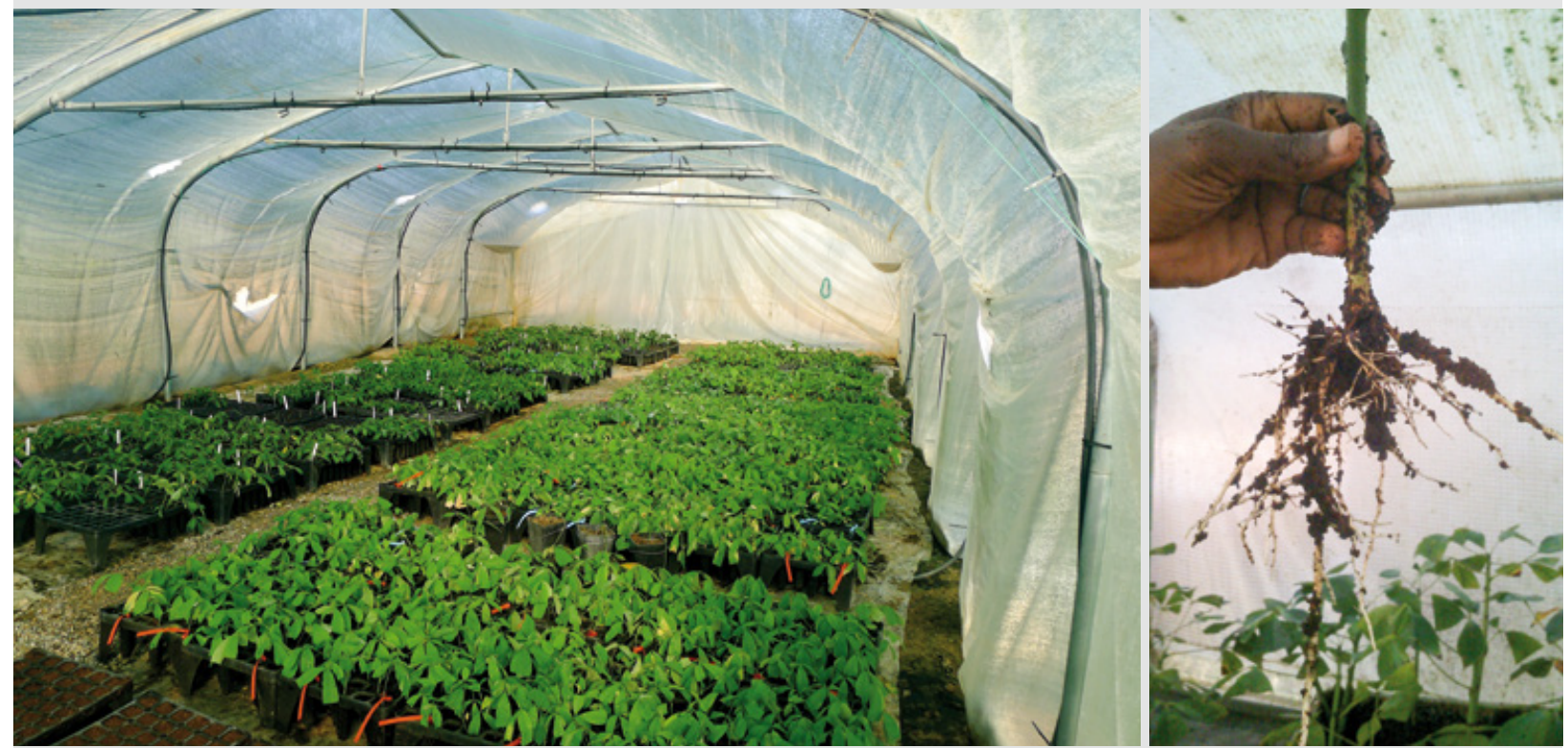

Photos 8.

Production of industrial rubber tree clones by rooted cuttings in SoGB facilities (left) and the adventitious root system of a 3 month-old cutting of the mature clone PB217 consisting of numerous lateral roots and a single tap root-like one (right).

Photos A. Masson. 

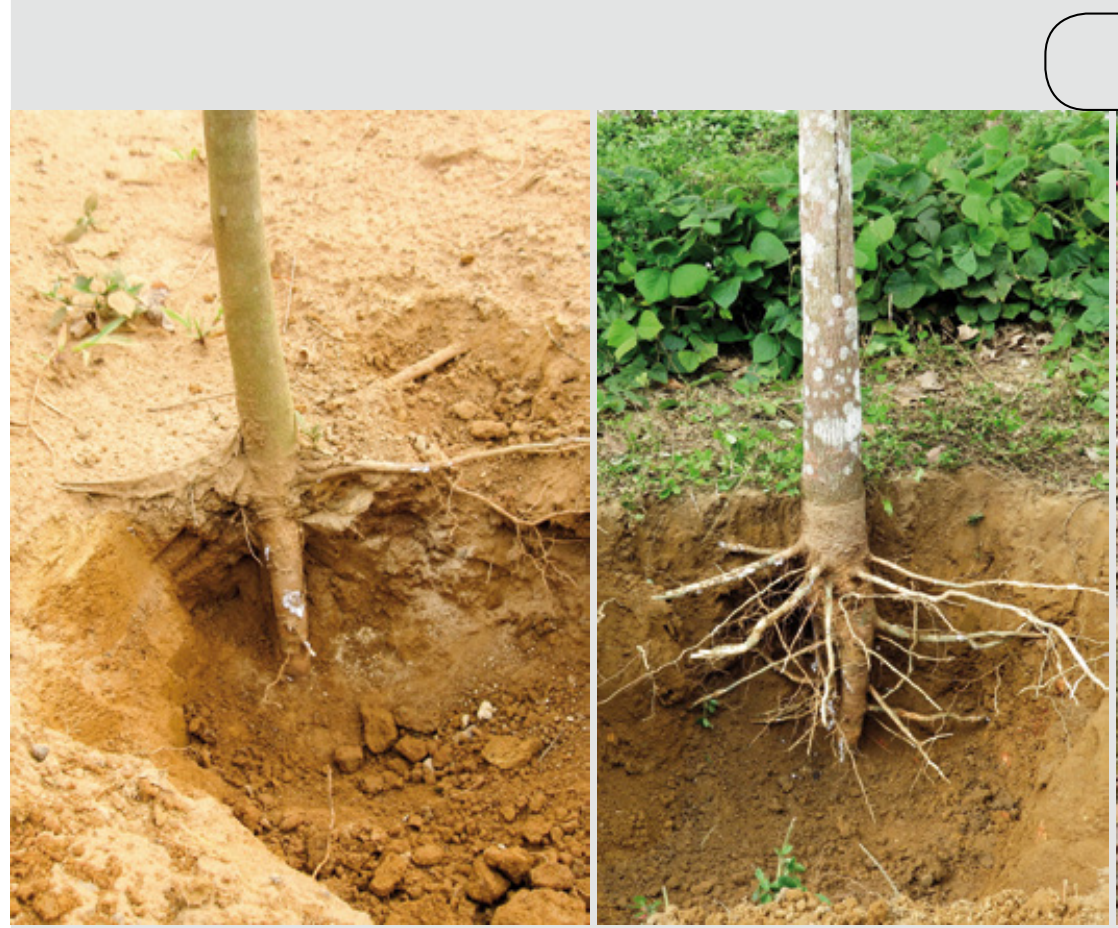

BOIS ET FORÊTS DES TROPIQUES, $2017, \mathrm{~N}^{\circ} 332$ (2) PLANTATION CLONALE D'ARBRE / LE POINT SUR.

Photos 9.

Adventitious root systems produced by cutting- (left) and microcutting-derived rubber trees (middle and right) $1.5 \mathrm{yr}, 3 \mathrm{yrs}$ and $19 \mathrm{yrs}$ respectively after planting at SoGB.

Photos O. Monteuuis and A. Masson.

(Monteuuis, unpublished results). Encouraging results were reported on the influence of shoot developmental stage on shoot apex responsiveness in primary culture (Lardet et al., 1990) and on the promoting effect of apex micrografting on in vitro capacity for adventitious rooting (Perrin et al., 1994), but surprisingly without follow up. Several years ago, Lardet (1987), then Perrin et al. (1994) acknowledged that in vitro micropropagation of $H$. brasiliensis mature clones had been hindered by insufficient capacity of the explants for shoot elongation and adventitious root formation. It seems that the situation has not radically improved since then. Despite substantial investment during the past 40 years, industrial $H$. brasiliensis clones can still not be efficiently enough mass micropropagated in vitro to meet the requirements of large scale production (Venkatachalam et al., 2007). The procedure developed mostly for seedlings and consisting of four successive steps and different culture media remains too heavy and costly to be operational (Montoro et al., 2012). In addition to an overall lack of organogenic responsiveness (Venkatachalam et al., 2007), a too high proportion of the shoots produced in vitro die during the acclimatization process to ex-vitro conditions (Dibi et al., 2010; Masson , 2017).

$H$. brasiliensis is one of the very few tree species for which somatic embryos or emblings can be obtained from mature genotypes using anthers or seed integuments as primary explants (Carron et al., 1989; 1995). These emblings exhibit all the anatomical and morphological characteristics of seedlings, even though they are clonal offspring from mature genotypes. Emblings differ in this respect from adventitiously rooted cuttings and microcuttings. Mass clonal production of rubber trees by emblings is however currently not realistic because of the very low efficiency of this technique, especially as far as germination and plant conversion rates are concerned (Venkatachalam et al., 2007). Up to now, it can be applied only to a very limited number of clones of industrial interest that are not necessarily the best ones. Moreover, the emblings produced are prone to somaclonal variations. The risks have been assumed to vary according to the genotypes and the protocols used, long-term maintained somatic embryogenesis procedures being more exposed (Compagnon, 1986; Montoro et al., 2012). Micropropagation by axillary budding can alternatively be used for amplifying the numbers of emblings produced in vitro.

In spite of these problems, several emblings and microcuttings have been produced during all these years and reached the stage of being field planted. Unfortunately this has been possible so far only for a few responsive industrial clones and not in sufficient numbers to meet the requirement of proper statistical designs for reliable field assessment (Venkatachalam et al., 2007). Notwithstanding these weaknesses, the observations drawn from different trials scattered here and there with microcutting- and embling-derived plants of various ages are encouraging (Carron et al., 1997; Montoro et al., 2012). For instance, emblings of clones PB260 and to lesser extent of PR107 were reported to have a more vigorous growth than the same clones produced by grafting (Carron et al., 1998). Also, self-rooted microcuttings and emblings were noticed to appear similar overall, when not better and more vigorous in field conditions than budded representatives of the same clones (Carron et al., 1997; 2000). They can be greater in girth, in volume and production of latex than the same genotypes grafted (Dibi et al., 2010). For example, an increase of $9.9 \%$ to $16.8 \%$ in trunk volume and of $3.5 \%$ to $32.3 \%$ in dry rubber production per tree was observed for microcuttings-derived plants compared to grafts of certain clones (Dibi et al., 2010). In SoGB, microcuttings that were rooted in vitro exhibited once field-established root systems which were very similar 


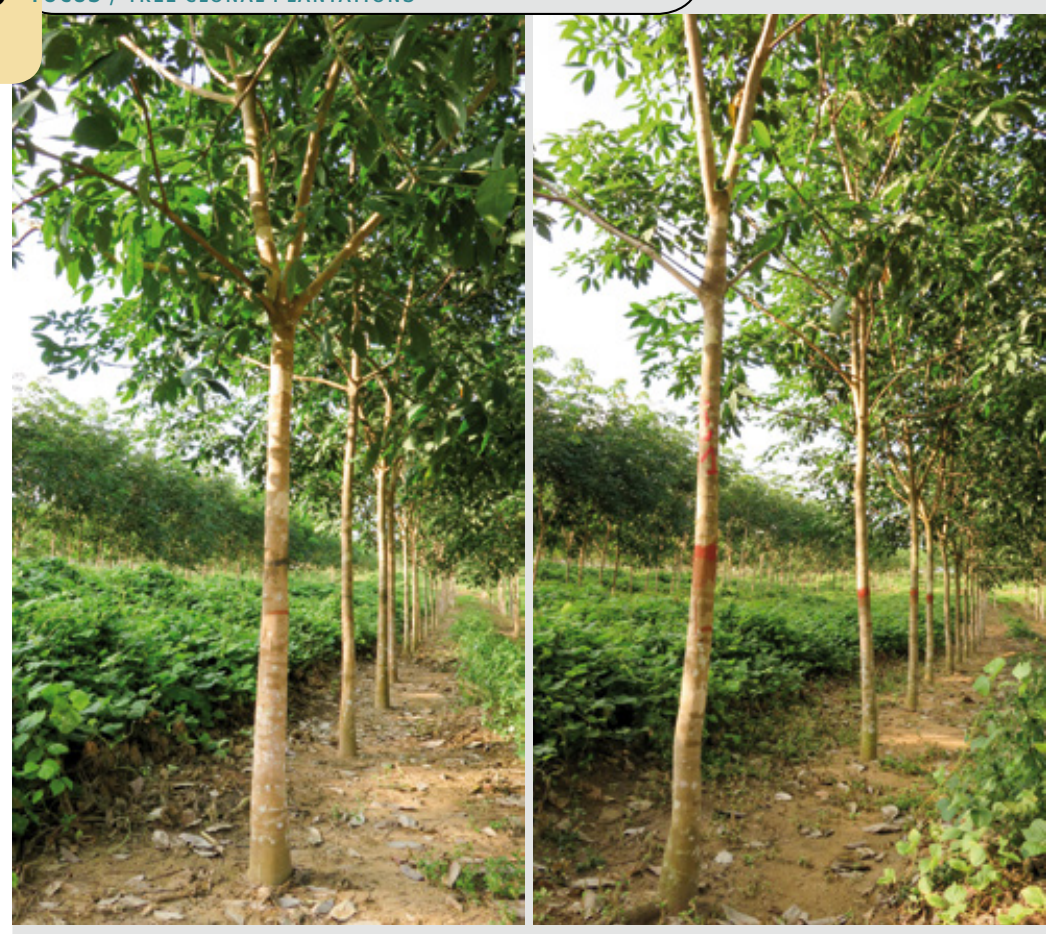

Photos 10.

3 year-old field trial comparing rooted cuttings (left) and budded plants (right) of the same industrial clone at SoGB. Photos A. Masson. ii) the quality of these later compared to embryo-derived root systems with a proper tap root. Another disadvantage is to start anew a selection program mainly based on the quality of the adventitiously produced root system, without, contrary to self-rooted industrial clones, any guarantee of the superiority of the aerial portion. As assumed with reference to fruit tree varieties (Hartmann et al., 1997) and demonstrated more specifically for the rubber tree (Leong and Yoon, 1978; Cardinal et al., 2007), crown x rootstock clone interactions are likely to have a determining influence on the "biclone" behavior. Consequently each scion $X$ rootstock clone combination must be tested in different environments.

Such comparative analyses must be carried out rigorously in conditions representative of commercial practices, with large enough numbers of observations and replicates for all the different clones of industrial interest that can be self-rooted (photos 10). Special consideration must be devoted also to the economic aspects, comparing the cost of establishing and managing grafted vs self-rooted clonal plantations and the respective returns.

Recent developments (Masson et al., 2013) have demonstrated the good prospects of resorting to nursery techniques for mass producing in situ mature selected industrial clones of rubber trees, whereas tissue culture techniques have failed to meet these goals so far, despite large investments (Venkatachalam et al., 2007). For eucalypt hybrid to those of seedlings, consisting of tap-root like and more superficial horizontal roots, consistent with other reports (Carron et al., 2000). The rooted cuttings from industrial clones obtained more recently behave similarly (photos 9). But again, these observations are still too scanty and restricted to too small samples to prove indubitably the superiority of self-rooted clones over grafted ones.

\section{Prospects and remaining issues}

Practically, the future of self-rooted $H$. brasiliensis clones remains strongly dependent on two main issues:

- The first one is the possibility to produce industrial clones on their own roots in sufficient numbers and cost-effectively enough to be mass utilized for large scale plantings.

- Then comes the question of assessing the field superiority of self-rooted clones compared to the same clones grafted and, if reliably proven, to what extent and for which clones, bearing in mind that none of them has ever been tested on its own roots yet. This entails to re-evaluation of industrial clones that can be mass rooted on their own roots on a wide range of potentially suitable soil conditions (Watson, 1989).

This latter option seems more realistic than the clonal rootstocks strategy (Simmonds, 1989; Carron et al., 2009a; Montoro et al., 2012) for several reasons. First, rootstock clones have to be mass produced by adventitious rooting. This implies that they will be exposed to the same conditions as mature selected industrial clones i.e.: i) the inhibitory effect of ageing on the capacity to form adventitious roots and clones too, appropriate nursery methods were found to be more efficient for operational uses than in vitro micropropagation (Monteuuis, 2016). During the past decades, the usefulness of nursery techniques may have been too much downplayed in favour of tissue culture. In vitro culture should not be too much disconnected from the natural environment from where explants can be introduced more easily for greater tissue culture success. Benefitting downstream from nearby nursery facilities can also be quite helpful for the rooting/acclimatization process, as demonstrated for teak for instance (Monteuuis, 2000). We do believe in a wise combination of nursery and in vitro vegetative propagation methods that can complement each other synergically for greater overall efficiency.

The clones that cannot be mass produced on their own roots with the efficiency required for industrial plantations can be used as stockplants for budwood gardens. This will prevent the risks of grafting genetically illegitimate shoots that could arise from unselected rootstock used for establishing budwood gardens with budded stockplants. Moreover, the physiological rejuvenation required for producing self-rooted stockplants can benefit the grafted clones, several reports mentioning the superiority for different criteria of rejuvenated scions over more mature ones (Dijkman, 1951; Carron et al., 2007; Montoro et al., 2012), notwithstanding clonal differences (Carron et al., 2009b; Masson, unpublished results). 


\section{Conclusion}

Superiority of latex yield by self-rooted industrial clones of rubber trees over grafted ones has been anticipated for more than one century. This issue is becoming of overriding importance considering the increasing pressure on land availability reducing thereby the prospects of expanding the area of industrial rubber tree plantations. The recent exhibition of the possibility of rooting cuttings of any industrial $H$. brasiliensis clone in sufficient numbers for setting up reliable comparative field trials is expected to soon provide a definite answer to this old question. Then, if the answer is positive and latex yield can be significantly increased using clones on their own roots instead of grafts, the future of self-rooted rubber-tree clonal plantations will ultimately be dependent on economic aspects.

\section{Acknowledgements}

The authors are greatly indebted to Dr Garth Nikles for his suggestions on the formulation of this paper.

\section{References}

Baulkwill W. J., 1989. 1. The history of natural rubber production. In: Rubber, Eds Webster C. C. and Baulkwill W. J., Longman Scientific and Technical, Essex, UK, 1-56.

Cardinal A. B. B., de Souza Gonçalves P., Martins A. L. M., 2007. Stock-scion interactions on growth and rubber yield of Hevea brasiliensis. Sciencia Agricola (Piracicaba, Braz.), 64 (3): 235-240.

Carron M. P., Enjalric F., Lardet L., Deschamps A., 1989. Rubber (Hevea brasiliensis Müll. Arg.). In: Biotechnology in Agriculture and Forestry, Vol. 5, Trees II, Ed. Y. P. S. Bajaj. Springer-Verlag, Berlin, 222-245.

Carron M. P., Etienne H., Michaux-Ferrière N., Montoro P., 1995. III.8. Somatic embryogenesis in rubber tree (Hevea brasiliensis Müll. Arg.). In: Biotechnology in Agriculture and Forestry, Vol. 30, Somatic Embryogenesis and Synthetic Seed, Ed. Y. P. S. Bajaj. Springer-Verlag, Berlin, 353-369.

Carron M. P., Dea B. G., Tison J., Leconte A., Keli J., 1997. Field growth of Hevea brasiliensis clones produced by in vitro culture. Plantations, Recherche, Développement, 4 (4): 264-273.

Carron M. P., Lardet L., Dea B. G., 1998. Hevea micropropagation by somatic embryogenesis. Plantations Recherche, Developpement, 5 (3): 187-194.

Carron M. P., Le Roux Y., Tison J., Dea B. G., Caussanel V., Clair J., Keli J., 2000. Compared root system architectures in seedlings and in vitro plantlets of Hevea brasiliensis, in the initial years of growth in the field. Plant and Soil, 223: 73-85.
Carron M. P., Granet F., Kéli J., 2007. Budding from rejuvenated clones: A good compromise between micropropagation and conventional budding. In: Natural rubber industry: $R$ and $D$ achievements and challenges, International Rubber Conference 2007, Siem Reap, Cambodia, 12-13 November 2007. CRRI, IRRDB, Phnom Penh, 367-373.

Carron M. P., Nurhaimi-Haris, Sumaryono, Sumarmadji, Granet F., Kéli J., Montoro P., 2009a. The rootstock clones in rubber tree: a new varietal type toward the rejuvenated bi-clone. In: Supriadi M., Suryaningtyas H., Siswanto, Nurhaimi-Haris, Sumaryono (Eds). Proceedings of the International Workshop on Rubber Planting Materials. Medan, Indonesia: Indonesian Rubber Research Institute. IRRDB Workshop on Rubber Planting Materials, 2008/10/28-29, Bogor, Indonesia, 89-95.

Carron M. P., Lardet L., Lecomte A., Dea B. G., Kéli J., Granet F., Julien J., Teerawatanasuk Kannikar, Montoro P., 2009 b. Field trials network emphasizes the improvement of growth and yield through micropropation in rubber tree (Hevea brasiliensis, Müll.-Arg.). In: Proceedings of the third international symposium on acclimatization and establishment of micropropagated plants, University of Algarve, Faro, Portugal, September 12-15, 2007, ISHS, Acta Horticulturae, 812: 485-492.

Chrestin H., Sookmark U., Trouslot P., Pellegrin F., Nandris D., 2004. Rubber Tree (Hevea brasiliensis) Bark Necrosis Syndrome III: A Physiological Disease Linked to Impaired Cyanide Metabolism. Plant disease, 88 (9): 1047.

Clément-Demange A., Priyadarshan P. M., Tran Thi Thuy Hoa, Venkatachalam P., 2007. Hevea rubber breeding and genetics. In: Plant breeding reviews, volume 29. Ed. Janick J. Hoboken, J. Wiley, 177-283.

Combe J. C., Du Plessix C. J., 1974. Étude du développement morphologique de la couronne de Hevea brasiliensis (Müll. Arg. Euphorbiacées-Crotonoïdées). Annales des Sciences Forestières, 31 (4): 207-228.

Compagnon P., 1986. Le Caoutchouc naturel : biologie, culture, production. Techniques Agricoles et Production Tropicales, Maisonneuve \& Larose, 595 p.

Dibi K., Boko C., Obouayeba S., Gnagne M., Dea G. B., Carron M. P., Anno A. P., 2010. Field growth and rubber yield of in vitro micropropagated plants of clones PR 107, IRCA 18 and RRIM 600 of Hevea brasiliensis (Müll.-Arg.). Agriculture and Biology Journal of North America, 1 (6): 1291-1298.

Dijkman M. J., 1951. Hevea. Thirty years of research in the Far East. University of Miami Press, 329 p.

Edgar A. T., 1958. Manual of rubber planting (Malaya). Incorporated Society of Planters, Kuala Lumpur, 705 p.

Hallé F., Martin R., 1968. Étude de la croissance chez l'hévéa (Hevea brasiliensis Müll. Euphorbiacées Crotonoidées). Adansonia, 2 (8): 475-503.

Hallé F., Oldeman R. A. A., Tomlinson P. B., 1978. Tropical trees and forests. Springer Verlag, Berlin, $441 \mathrm{p}$. 
Hartmann H. T., Kester D. E., Davies Jr F. T., Geneve R. L., 1997. Plant Propagation: Principles and Practices. Prentice-Hall, Inc., Englewood Cliffs, New Jersey, Sixth edition, $770 \mathrm{p}$.

Lachaud S., 1975. Incompatibilité des greffes et vieillissement chez les végétaux. II. L'incompatibilité des greffes et ses rapports avec le vieillissement. L'Année Biologique, 14: 97-28.

Lardet L., 1987. Amélioration des conditions du microbouturage de l'Hevea brasiliensis (Müll. Arg.). Thèse de doctorat de l'Université des Sciences et Techniques du Languedoc, Montpellier II, France, 242 p.

Lardet L., Enjalric F., Carron M. P., 1990. Culture d'apex d'Hevea brasiliensis (Müll. Arg.) : influence du stade morphogénétique et de l'âge des explants. Comptes Rendus de l'Académie des Sciences, Série 3, Sciences de la Vie, 310 : 195-202.

Leconte A., Nicolas D., 1985. Stérilité mâle chez l'hévéa : Cas du clone GT1. Caoutchoucs et Plastiques, 649 : 127-129.

Leong W., Yoon P. K., 1978. Effect of interstock on growth of Hevea. Journal of Rubber Research Institute of Malaya, 26 (3): 99-104.

Levandowsky D. W., 1959. Multiplication de l'Hevea brasiliensis par bouture. Revue Générale du Caoutchouc et des Plastiques, 36 (9), 1132-1141.

Masson A., 2017. Usefulness of in vitro micropropagation for establishing plantations of self-rooted Hevea brasiliensis industrial clones. In: Proceedings of the Sixth International Symposium on Production and Establishment of Micropropagated Plants. San Remo, Italy, April 19, 2015, ISHS 2017, Acta Horticulturae, 1155: 595- 598.

Monteuuis O., 1993. Current advances in clonal propagation methods of some indigenous timber species in Sabah (Malaysia). In: "Recent Advances in Mass Clonal Multiplication of Forest Trees for Plantation Programmes", Proceedings, UNDP/FAO Regional Project on Improved Productivity of ManMade Forests Through Application of Technological Advances in Tree Breeding and Propagation (FORTIP), Cisarua, Bogor, Indonesia, 1-8 Dec., 1992, 168-193.

Monteuuis 0., 2000. Propagating teak by cuttings and microcuttings. In: Proceedings of the international seminar "Site, technology and productivity of teak plantations", FORSPA, Publication N²4/2000, Teaknet Publication, 3: 209-222.

Monteuuis 0., 2016. Micropropagation and production of forest trees. In: Vegetative propagation of forest trees. Part 1: Development and trends in vegetative propagation of forest trees, Eds Y. S. Park, J. M. Bonga, H. K. Moon), NIFOS, Korea,32-55.

Montoro P., Carron M. P., Granet F., Lardet L., Leclercq J., Dessailly F., Martin F., Uche E., Rio M., Oliver G., 2012. Development of new varietal types based on rejuvenation by somatic embryogenesis and propagation by conventional budding or microcuttings in Hevea brasiliensis. In: Proceedings of the Seventh International Symposium on In Vitro Culture and Horticultural Breeding, Ghent, Belgium, September 18-22, 2011, ISHS, Acta Horticulturae, 961: 553-576.
Perrin Y., Lardet L., Enjalric F., Carron M. P., 1994. Rajeunissement de clones matures d'Hevea brasiliensis (Müll. Arg.) par microgreffage in vitro. Canadian Journal of Plant Science, $74: 623-630$.

Pochet P. D., 1965. Le système radiculaire des boutures d'Hevea brasiliensis Müll. Arg. Agricultura, 13 : 213-240.

Priyadarshan P. M., 2011. Biology of Hevea Rubber. CAB International, 226 p.

Simmonds N. W., 1989. 3. Rubber breeding. In: Rubber, Eds Webster C. C. and Baulkwill W. J. Longman Scientific and Technical, Essex, UK, 85-124.

Stahel G., 1947. A New Method of Rooting Cuttings of Hevea and Other Trees. Tropical Agricultura (Trinidad), 24 (1-3): 4-6.

Tinley G. H., Garner R. J., 1960. Developments in the propagation of clones of Hevea brasiliensis by cuttings. Nature, 4722: 407-408.

Venkatachalam P., Kumari Jayasree P., Sushmakumari S., Jayashree R., Rekha K., Sobha S., Priya P., Kala R. G., Thulaseedharan A., 2007. Current Perspectives on Application of Biotechnology to Assist the Genetic Improvement of Rubber Tree (Hevea brasiliensis Müll. Arg.): An Overview. Functional Plant Science and Biotechnology, 1 (1): 1-17.

Warburg O., 1902. Les plantes à caoutchouc et leur culture. Challamel, Paris, 307 p.

Watson G. A., 1989. 4. Climate and soil. In: Rubber, Eds Webster C. C. and Baulkwill W. J. Longman Scientific and Technical, Essex, UK, 125-164.

Webster C. C., 1989. 6. Propagation, planting and pruning. In: Rubber, Eds Webster C. C. and Baulkwill W. J. Longman Scientific and Technical, Essex, UK, 195-244.

Webster C. C., Baulkwill W. J., 1989. Rubber. Longman Scientific and Technical, Essex, UK, 614 p.

Webster C. C., Paardekooper E. C., 1989. 2. The botany of the rubber tree. In: Rubber, Eds Webster C. C. and Baulkwill W. J. Longman Scientific and Technical, Essex, UK, 57-84.

Whitby G. S., 1919. Variation in Hevea brasiliensis. Annals of Botany, 33: 313-321.

Wycherley P. R., 1969. Breeding of Hevea. Journal of Rubber Research Institute of Malaya, 21: 38-55. 